\title{
Woda w mur lub wyjście przez okno z betonu. O kilku graffiti Banksy'ego
}

ANNA MROZEWICZ

W książce zatytułowanej Evictions. Art and Spatial Politics (Eksmisje. Sztuka i polityka przestrzeni) amerykańska badaczka i socjolożka sztuki Rosalyn Deutsche, omawiając pracę Krzysztofa Wodiczki Homeless Projection (Projekcja bezdomnych) zauważa, że dzięki ingerencji artysty w przestrzeń publiczną „[e]ksmitująca architektura staje się architekturą eksmitowanych"[1]. Zdaniem tym można z powodzeniem określić przesunięcie znaczeń, jakiego dokonują prace graffiti, umieszczone w 2005 roku przez brytyjskiego artystę Banksy'ego na murze dzielącym część tak zwanych terenów okupowanych - Zachodni Brzeg - od terytorium Izraela. Parafrazując Deutsche: eksmitujący mur staje się murem eksmitowanych.

Powodów, by o tych pracach przypomnieć, ale też przyjrzeć im się krytycznie, wskazać można kilka: na temat pochodzącego z Brystolu Banksy’ego, artysty (czy, jak mówią niektórzy: terrorysty) street artu, zrobiło się w ostatnich miesiącach głośno w związku z pokazywanym w polskich kinach od listopada 2010 quasi-dokumentalnym filmem Wyjście przez sklep z pamiątkami, który jest wielopoziomową manipulacją oscylującą wokół zagadnień sztuki, jej rynku, kontrkultury, kultury masowej, a także samego medium filmo-

[1] R. Deutsche, Evictions. Art and Spatial Politics, London 1996, s. 39 (w oryginale: "An evicting architecture becomes an architecture of the evicted").

[2] Z. Krohn, J. Lagerweij, Concrete Messages. Street Art on the Israeli - Palestinian Separation Barrier, Dokument Press 2010, s. 122.

[3] H. Foighel, Graffiti slår huller i den israelske mur [Graffiti dziurawi izraelski mur], recenzja książki Concrete Messages, „Politiken” (sekcja „Kultur”), 21.12.2010, s. 1. wego. Zapytać można, czy prace graffiti na murze między Izraelem a obszarami palestyńskimi wpisują się w konkluzję filmu, że nawet najbardziej subwersywna sztuka poddaje się $\mathrm{w}$ końcu regułom rynku, z którego nie ma wyjścia innego niż przez „sklep z pamiątkami”. Kolejnym powodem może być wydana niedawno w Danii, Szwecji i Holandii książka Concrete Messages, jako pierwsza dokumentująca niemal wszystkie prace wykonane na murze od 2005 roku (Banksy'ego nazwać można pionierem) przez w sumie szesnastu artystów z całego świata. Książka ta, a właściwie album z setką barwnych zdjęć i towarzyszącymi im wypowiedziami twórców (Banksy jako jedyny nie udzielił wywiadu) powstała $\mathrm{z}$ inicjatywy dwóch młodych wolontariuszek, które przebywały na Zachodnim Brzegu w 2008 roku Dunki Zii Krohn i Holenderki Joyce Lagerweij. Jedną z wielu zasług tej książki jest udokumentowanie materiału, który lada dzień może zmienić się lub zniknąć zarówno z powodu ciągle niepewnej sytuacji politycznej w tym regionie, jak i dlatego, że specyfiką sztuki graffiti jest efemeryczność, na co Banksy zwraca uwagę w swoim filmie. Nastąpiło to krótko po ukończeniu zdjęć przez autorki w styczniu 2009 roku w okolicy posterunku kontrolnego w pobliżu Betlejem pojawiła się niebieska pozioma linia, ciągnąca się przez znaczną część prac graffiti, prawdopodobnie w proteście przeciwko traktowaniu muru jako atrakcji turystycznej (podobna akcja miała miejsce na murze berlińskim w 1986 roku, jak podają autorki[2]). W końcu innym jeszcze powodem, by napisać o tych pracach jest fakt, że nie są one tak jednoznaczne, jak mogłoby się wydawać[3], a wręcz przeciwnie - można je czytać jako wielopoziomowy dialog nie tylko z otaczającą rzeczywistością i miejscem, 
w które są wpisane, ale też symboliką ikonosfery tego miejsca.

Mur, na którym wykonane zostały graffiti, określany jako „Israeli West Bank barrier” (izraelska bariera na Zachodnim Brzegu) lub bardziej neutralnymi terminami „barrier” (bariera), „separation barrier” (bariera separacyjna) lub „West Bank barrier” (bariera na Zachodnim Brzegu) [4], przez zwolenników nazywany też ogrodzeniem/murem bezpieczeństwa („security fence/wall”), a przeciwników murem apartheidu („,apartheid wall”[5]), przez Palestyńczyków zaś ścianą segregacji rasowej („racial segregation wall”), budowany jest na zlecenie rządu izraelskiego od 2002 roku. Obecnie zatwierdzona przez rząd Izraela długość bariery wokół Zachodniego Brzegu to $725 \mathrm{~km}$ (z czego ponad $400 \mathrm{~km}$ wzniesiono do tej pory, a około dwadzieścia pięć procent jest w trakcie budowy). Strukturę bariery tworzy w przeważającej części drut kolczasty, ze strefami wyłączonymi z ruchu po obu stronach i często z rowami przeciwsamochodowymi, w sumie na około sześćdziesiąt metrów szerokości. Około pięć procent długości bariery, głównie w obszarach miejskich (okolice Jerozolimy, Ramallah i Betlejem), to betonowy mur, sięgający niekiedy ośmiu metrów wysokości, gruby na około trzy metry. Na całej długości bariery znajdują się regularnie rozmieszczone punkty obserwacyjne, a także bramy kontrolowane przez żołnierzy izraelskich.

Celem muru ma być, według izraelskiego rządu, ograniczenie palestyńskich ataków w Izraelu (często uważanych za terrorystyczne), co częściowo poskutkowało[6], ale też zapewnienie spokoju zwyczajnym obywatelom po stronie palestyńskiej[7]. Faktem jest jednak także, że mur w znacznym stopniu ogranicza mobilność Palestyńczyków oraz ich swobodny dostęp do udogodnień takich jak służba zdrowia, ośrodki edukacyjne, religijne i kulturalne, a także do pracy, rodzin pozostałych po drugiej stronie muru, ziemi, dróg, wody, rolnictwa itp. Sama trasa muru jest kontrowersyjna, mówi się o niej jako o próbie zaanektowania przez Izrael terenów zajmowanych przez palestyńskich osadników[8].

Niezależnie od wpływu, jaki wywiera na życie ludzi po obu stronach, mur ten jest znakiem konfliktu i wpisuje się w długą historię muru jako bariery mającej zapobiec przemieszczaniu się czy służącej oddzieleniu dwóch lub więcej populacji. Do najbardziej znanych w historii świata należy na pewno Wielki Mur Chiński, budowany w wielu fazach od piątego wieku przed Chrystusem aż do siedemnastego wieku, chroniący północną granicę Chin przed najazdami obcych plemion. Jednymi z najstarszych są mur Hadriana w północnej Brytanii, budowany w latach 121-129 n.e., i fortyfikacja Danevirke, wznoszona przez duńskich Wikingów od połowy VII do XII wieku w dzisiejszym SzlezwikuHolsztynie jako obrona przed atakami wrogich plemion z południa. Historia dwudziestego wieku naznaczona jest „cieniem” muru berlińskiego, a w epoce po jego obaleniu do

[4] Terminy stosowane przez ONZ i zalecane dziennikarzom BBC jako neutralne, zob. http:// news.bbc.co.uk/newswatch/ifs/hi/newsid_ 6040000/newsid_6044000/6044090.stm\#barrier (data odczytu: 21.01.2011); termin „separation barrier" jest stosowany m.in. przez profesora prawa międzynarodowego na Uniwersytecie Hebrajskim w Jerozolimie, Davida Kretzmera, zob. http://farescenter.tufts.edu/publications/pharos/ fall06.pdf, s. 6 i 9 (data odczytu: 21.01.2011); neutralnym terminem posłużyły się też autorki książki Concrete Messages w podtytule, zob. op.cit. [5] Tak też nazwał mur Międzynarodowy Trybunał Sprawiedliwości w Hadze w 2004 roku, określając ideę jako niezgodną z prawem międzynarodowym (dotyczy to m.in. linii przebiegu bariery, która jest niezgodna z tzw. „zieloną linią," a więc do 1967 roku granicą między Zachodnim Brzegiem a Izraelem).

[6] Trudno jednak stwierdzić, co bardziej się do tego przyczyniło: wzniesienie muru czy złożone okoliczności polityczne, zob. Concrete Messages, op.cit., s. 6.

[7] Z. Krohn, J. Lagerweij, op.cit., s. 6.

[8] Ibidem, s. 6. Zob. też http://en.wikipedia.org/ wiki/Israeli_West_Bank_barrier (data odczytu: 21.01.2011). 
głośnych wydarzeń należało postawienie przez władze czeskiego miasta Ústí nad Łabą muru oddzielającego bloki zamieszkałe przez Romów od reszty osiedla[9].

Bariera wznoszona między terenami izraelskimi i palestyńskimi jest zatem nie tylko fizyczną granicą, murem organizującym przestrzeń geopolityczną, lecz także granicą pojęciową, przebiegającą w przestrzeni mentalnej, „ścianą w umysłach ludzi” (jak Vaclav Havel określił mur w Ústí nad Łabą, a niemiecki pisarz Peter Schneider mur berliński[10]). Jest indeksem konfliktu i znakiem dominacji, władzy. Jest znakiem próby uczynienia niewidzialnymi tych, którzy są niewygodni, ustalaniem granicy pomiędzy wnętrzem (centrum) a zewnętrzem (marginesem podporządkowanym centrum). Paradoksalnie jednak, jak każdy tego typu mur, próbując uczynić niewidocznym, uwidacznia, dzieląc, jednocześnie łączy.

[9] Mur ten został potępiony przez ówczesnego prezydenta Czech Vaclava Havla i europejską opinię publiczną, w wyniku czego rozebrano go. Zob.: Tabor Europy, „Wprost” 2000, nr 6, http:// www.wprost.pl/ar/3128/Tabor-Europy/ (data odczytu: 22.01.2011).

[10] Dokładnie „mur w głowie”, zob. N. Barfoed, Hotel Donau. Essay om det andet Europa, København 1988, s. 9.

[11] H. Lefebvre, The Production of Space, trans. by D. Nicholson-Smith, Oxford 1991 (oryginalny tytuł: La Production de l'espace, Paris 1974).

[12] Praca Wodiczki The Homeless Projection: A Proposal for the City of New York, 1986, była zaplanowana jako interwencja w oficjalną architekturę placu Union Square w Nowym Jorku, ale pokazana została jedynie w galerii. Zob.

R. Deutsche, op.cit., s. 7.

[13] Jak wspomina jedna $\mathrm{z}$ autorek Concrete Messages, Zia Krohn, znacząca większość graffiti i napisów na murze wykonywana jest po stronie palestyńskiej, ponieważ nie jest to zabronione przez władze Izraela. Po stronie izraelskiej zabronione jest umieszczanie jakichkolwiek napisów czy graffiti na murze, określanym jako izraelska militarna bariera bezpieczeństwa (podaję za: korespondencja prywatna $\mathrm{z}$ autorką).
Jak pisze Deutsche, odwołując się do ukutego przez francuskiego socjologa Henri Lefebvre’a terminu „produkcja przestrzeni”[11], każda przestrzeń (miejska) jest polityczna, nierozdzielna od konfliktów społecznych $\mathrm{w}$ danym momencie historycznym. Jeśli w przypadku wspomnianej pracy Krzysztofa Wodiczki terenem planowanej interwencji była oficjalna przestrzeń miejska, dążąca do zatarcia swojej polityczności, nierównych relacji i konfliktów społecznych[12], tak w przypadku bariery oddzielającej Zachodni Brzeg od Izraela mamy do czynienia z sytuacją odwrotną - ogrodzenie i organizowana przez nie przestrzeń są manifestacją konfliktu, wyostrzeniem podziałów, umocnieniem istniejących nierówności. W przeciwieństwie też do większości miejsc, w których umieszcza graffiti i przeprowadza swoje akcje Banksy (czego wiele przykładów pokazano we wspomnianym filmie), a więc $w$ przestrzeniach miast zachodnich, mając na celu odsłonięcie istniejących, lecz maskowanych mechanizmów władzy, tu polem jego działania stało się miejsce w sposób wyraźny i otwarty naznaczone konfliktem i podziałami.

Seria dziewięciu graffiti, wykonanych przez Banksy'ego w sierpniu 2005 roku na odcinku muru na Zachodnim Brzegu Jordanu po stronie palestyńskiej[13] w okolicach Betlejem, Jerozolimy i Ramallah, nie jest w oczywisty sposób polityczna. Działanie artysty nie stanowi prostej krytyki istnienia muru, nie jest sprzeciwem posługującym się jednoznaczną satyrą, ośmieszeniem czy, jak w przypadku palestyńskich graffiti, komunikatem werbalnym. Utrzymane w przeważającej części w poetyce silnie iluzjonistycznej, zbliżonej bardziej do malarskiego fotorealizmu niż graffiti, zaskakując tematyką i skalą, integrując się wizualnie ze strukturą muru i jednocześnie pozostając w absurdalnej, wręcz groteskowej wobec niego sprzeczności, prace te odsłaniaja jego retorykę, dokonują przesunięcia znaczeń w ramach opozycji wnętrze-zewnętrze, kwestionują trwałość i pozorną niezniszczalność bariery. 


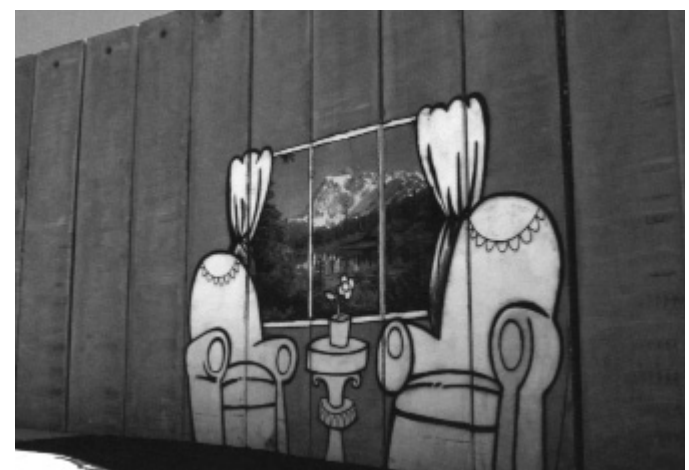

Il. 1. Banksy, Okno na zachodni Brzeg, 2005

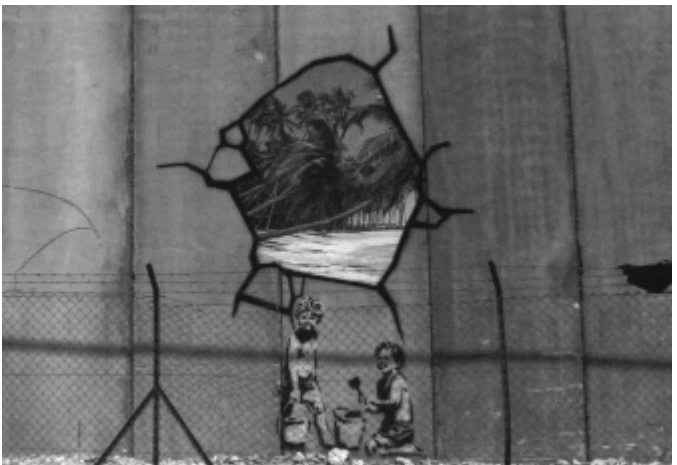

Il. 2. Banksy, Niepożądana interwencja

(Plażowi chłopcy), 2005

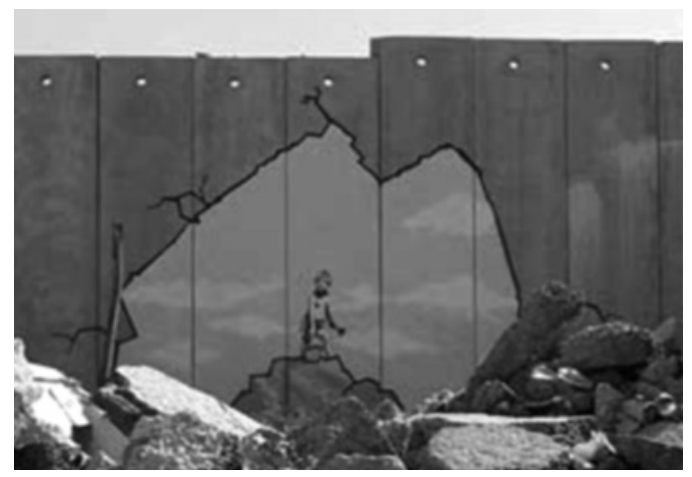

Il. 3. Banksy, Atak sztuki, 2005

Zanim przyjrzę się bliżej poszczególnym pracom, przytoczę komentarze Palestyńczyków, pytanych przez dziennikarza brytyjskiej stacji telewizyjnej BBC o opinię na temat graffiti wykonanych przez Banksy'ego.[14]

Krótki wywiad telewizyjny został przeprowadzony na tle pracy zatytułowanej Window on the West Bank (Okno na Zachodni Brzeg, il. 1). Krzesła, na których siedzą dziennikarz i jego poszczególni rozmówcy, ustawiono odpowiednio przed każdym z namalowanych na murze gigantycznych foteli.

Dziennikarz: Te obrazy zostały wykonane przez artystę z Wielkiej Brytanii. Co pani (pan) o nich myśli?

Młoda dziewczyna: Uważam, że dobrze, iż wiedzą, że tu jest problem, że o nas myślą.

Stary mężczyzna: To graffiti zostało tu umieszczone, by pokazać, że ściana ta jest więzieniem dla Palestyńczyków.

Młody chłopak: Nie rozumiem, jaki jest cel umieszczania tego graffiti tutaj.

Na stronie autorskiej Banksy’ego przytoczony został komentarz starszego Palestyńczyka, który powiedział artyście, że jego malowidła sprawiły, iż ściana stała się piękna. Gdy Banksy podziękował za tę uwagę, mężczyzna odparł: „Nie chcemy, aby ta ściana była piękna, nienawidzimy jej. Wracaj do domu" [15].

Graffiti Banksy'ego wykonane w 2005 ro$\mathrm{ku}[16]$ można podzielić na dwie grupy: prace, które posługują się quasi-malarskim językiem (efekt ten został osiągnięty przez wykorzystanie gotowych „fototapet”, przyklejonych do powierzchni muru) oraz graffiti wykorzystujące szablony, dzięki którym można uzyskać zamierzone formy (najczęściej w postaci płaskich plam barwnych) po wypełnieniu odpo-

[14] Zob.: http://news.bbc.co.uk/2/hi/ entertainment/4748063.stm (link do wywiadu po prawej stronie: BBC News: video and audio; data odczytu: 21.01.2011)

[15] Zob. http://arts.guardian.co.uk/pictures/ 0,1543331,00.html (data odczytu: 28.01.2011).

[16] W 2007 roku Banksy dodał jeszcze sześć prac na murze i pobliskich budynkach przy okazji zorganizowanej przez siebie wystawy Santa's Ghetto w Betlejem, do udziału w której zaprosił artystów $\mathrm{z}$ różnych krajów. Zob. Concrete Messages, op.cit., s. 39. Zob. też (data odczytu: 26.01.2011): http://articles.cnn.com/2007-12-03/world/ banksy.bethlehem_1_banksy-barrier-mangersquare?_s=PM:WORLD 
wiednią farbą w sprayu. Do pierwszej z tych grup, na której chciałabym się skupić, zaliczyć można: Okno na Zachodni Brzeg, Unwelcome Intervention (Niepożadana interwencja, il. 2), funkcjonująca też pod tytułem Beachboys (Plażowi chłopcy), Art Attack (Atak sztuki, il. 3) oraz dwie prace, które tytułuję Strażnik (il. 4) i Uchyl rąbka (il. 5). Do drugiej grupy zaliczam: Stable conditions (Stajniane/stabilne warunki), Balloon Debate (Debata w balonie), Escapism (Eskapizm), Cut it Out (Wyciać tutaj)[17]. Tytuły większości z tych prac oparte są na grze słownej, która dodatkowo zostaje udosłowniona lub wypaczona w warstwie wizualnej, dzięki czemu całość zyskuje ironiczny wydźwięk.

Prace należące do pierwszej grupy łączą nie tylko wspomniane cechy formalne, lecz także zamysł tematyczno-kompozycyjny, opierający się na pomyśle „przebijania”, na różne sposoby, betonowego muru. Niepożadana interwencja i Atak sztuki przedstawiają wybite w murze dziury, przy czym w tej ostatniej dziura sprawia wrażenie wybitej od „drugiej strony" muru. Wrażenie to wywołane jest po pierwsze dzięki umieszczeniu w centrum pola otworu postaci chłopca, który wydaje się wspinać po gruzach, przychodząc z „tamtej” strony ku widzowi. Po drugie, owa „dziura” namalowana została w taki sposób, że wizualnie integruje się nie tylko z błękitem rzeczywistego nieba, ale też ze stosem kamieni, leżących (co widać na jednym ze zdjęć) pod murem, w efekcie czego wyglądają one jak odłamy wybitego właśnie betonu. Okno na Zachodni Brzeg to, jak wskazuje tytuł, okno w murze, otwierające się na rozciągający się po „drugiej stronie” widok jeziora i szczytów górskich. Praca Strażnik oparta jest z kolei na zamyśle „odsłaniania” jednego z paneli muru jakby był miękką zasłoną, zaś Uchyl rąbka na

[17] Zdjęcia siedmiu prac można zobaczyć m.in. na stronie internetowej: http://arts.guardian.co. uk/pictures/image/0,8543,-10105256016,00.html (data odczytu 26.01.2011). Brakuje wśród nich graffiti zatytułowanych przeze mnie „Strażnik” oraz „Uchyl rąbka”.

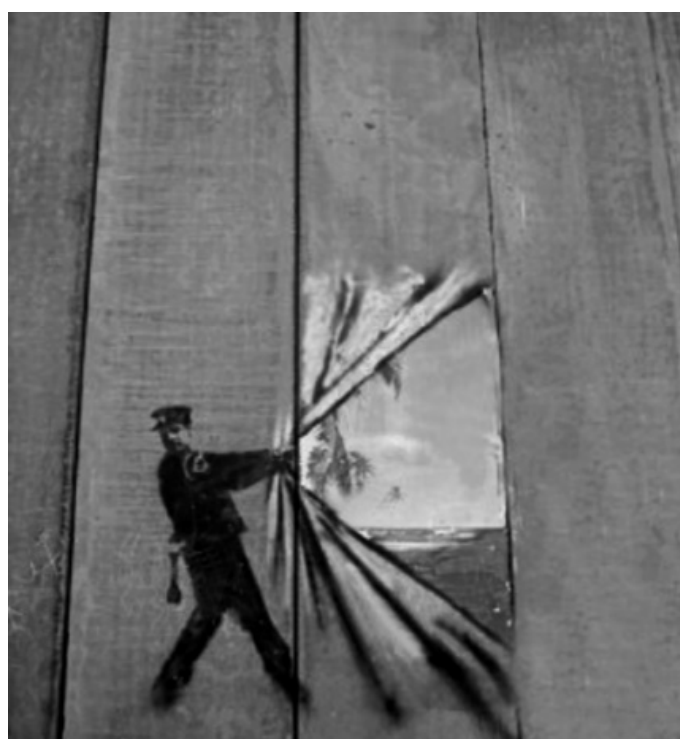

Il. 4. Banksy, Strażnik, 2001

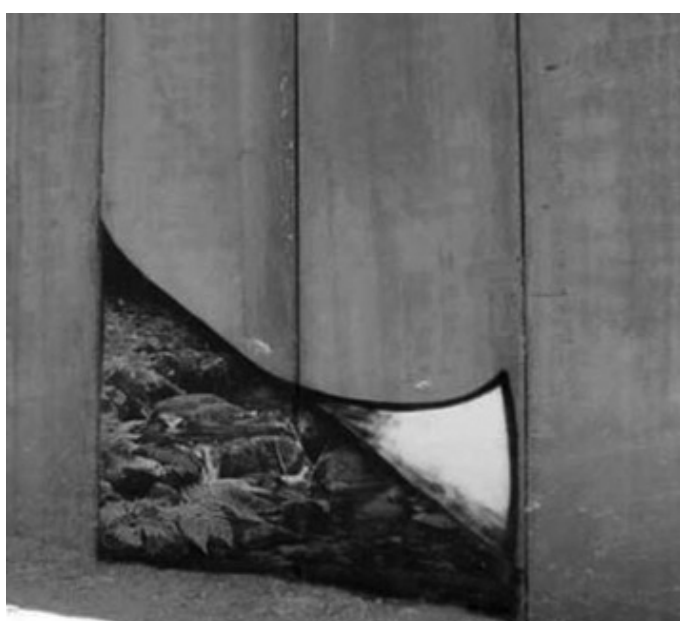

Il. 5. Banksy, Uchyl rąbka, 2005

unoszeniu fragmentu panelu w jego dolnym rogu niczym kartki papieru.

Kolejnym elementem wspólnym dla tych prac są widoki, roztaczające się „za murem”. Są to piękne, chciałoby się rzec dziewicze (nietknięte stopą ludzką), rajskie krajobrazy (lub ich fragmenty). Okno na Zachodni Brzeg ukazuje rozległy „alpejski” pejzaż górski z jeziorem, dziura w Ataku sztuki otwiera się na czyste niebo z białymi obłokami, przez co mur sprawia wrażenie miejsca położonego gdzieś 
w górach, wysoko nad ziemią. Strażnik i Niepożądana interwencja odsłaniają widoki tropikalnych plaż: na pierwszym z nich, za odchyloną przez strażnika „zasłoną”, widać ciągnący się w dali pas plaży z palmami i ciemnobłękitne morze. Niepożadana interwencja (lub Plażowi chłopcy) również ukazuje tropikalną plażę, tu jednak dwie trzecie górnej części pola obrazu wypełniają palmy, których intensywna zieleń odznacza się na tle równie intensywnego błękitu nieba. Uchyl rąbka odsłania górski strumyk obrośnięty zielonymi paprociami, którego dno prześwituje przez krystalicznie czystą wodę.

Zapytać można, jaką rolę w tych pracach pełni powracający w każdej z nich, dominujący motyw krajobrazu. Czy jest to jedynie, jak przewrotnie nazywa je twórca, „kilka fotografii z wakacji"?[18]

Niewątpliwie jest coś w stwierdzeniu, że obrazy te są jak wakacyjne pocztówki, ukazujące wyidealizowany, odpowiadający stereotypowym wyobrażeniom i najczęściej banalny widok. Kwestia ta staje się jednak interesująca, gdy zwrócimy uwagę, że w graffiti przedstawione zostały geograficznie różne krajobrazy, co jest szczególnie wyraźne, gdy porównamy dwie prace: Plażowych chłopców i Okno na Zachodni Brzeg.

Obie prace graffiti znajdują się na odcinku muru w okolicy Betlejem. Niepożądana interwencja (Plażowi chłopcy) umieszczeni zostali w niemożliwym do przeoczenia miejscu, codziennie mijanym przez dziesiątki turystów, udających się do Betlejem. Okno na Zachodni Brzeg również znajduje się w miejscu łatwo dostępnym, co widać we wspomnianym wywiadzie przeprowadzonym przez dziennikarza stacji BBC z przypadkowo spotkanymi przechodniami.

Niezwykle istotny dla interpretacji tych malowideł wydaje się fakt, że przedstawiają one dwa zupełnie odmienne krajobrazy: południowy (miejscowy) oraz północny, „alpejski”, czy ogólniej - kojarzony ze światem zachodnim. Obydwa widoki, utrzymane, jak wspomniałam, w poetyce fotorealizmu, silnie ilu-

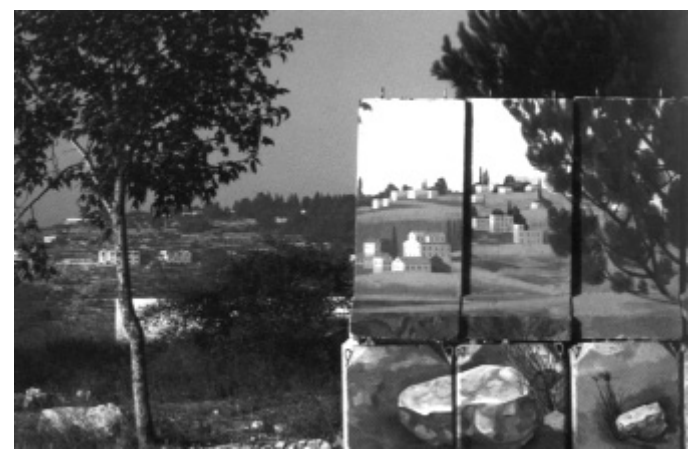

Il. 6. Miki Kratsman, Gilo, 2001

zjonistyczne, odwołują się do konwencji kartek pocztowych. Jednak dla widza europejskiego krajobraz w Plażowych chłopcach przywodzi na myśl co najmniej jeszcze jedno skojarzenie: Eden - Raj.

Sam pomysł malowania krajobrazu na murze dotyka najczulszych punktów tego regionu geopolitycznego: krajobraz jako pars pro toto ziemi, mur jako znak konfliktu, wydają się tu nierozdzielne. Ślad tego splecenia odnaleźć można w fotografii jednego z izraelskich artystów Miki Kratsmana (ur. 1959) zatytułowanej Gilo (il. 6), o kilka lat wyprzedzającej prace Banksy'ego. Widzimy na niej krajobraz południowych okolic Jerozolimy, z prawej strony w połowie przesłonięty przez betonowy mur, na którym odtworzony został ten sam, rozciągający się za nim krajobraz. W ten sposób reprezentacja krajobrazu na murze stapia się z rzeczywistym widokiem, jak gdyby mówiąc nam, że „mur” (ten mentalny) jest na trwałe wpisany w ziemię tego obszaru i blokuje bezpośredni do niej dostęp[19]. Wyraźnym nawiązaniem do konfliktu izraelsko-palestyńskiego jest też z pewnością motyw wody, poja-

[18] Taki komentarz Banksy’ego można było przeczytać na jego stronie autorskiej (http://www. banksy.co.uk/) w 2006 roku.

[19] Zdjęcie to przedstawia fragment faktycznego ogrodzenia, które rząd izraelski wzniósł w 2001 roku na peryferiach dzielnicy Gilo, leżącej na południowozachodnich przedmieściach Jerozolimy, po tym jak miejsce to stało się celem ataków ogniowych, przeprowadzonych przez radykalne 
wiający się aż w czterech z pięciu omawianych graffiti Banksy'ego. Dostęp do wody to jeden z głównych i najbardziej skomplikowanych punktów zapalnych tego konfliktu, a wybudowanie bariery jeszcze go zaogniło, ograniczając społeczności palestyńskiej możliwość korzystania $\mathrm{z}$ istniejących źródeł wody pitnej, jak i poszukiwania nowych[20].

Motyw krajobrazu i wyobrażenia kraju ojczystego odgrywają, jak podaje katalog do zorganizowanej sześć lat temu w Berlinie wystawy Die neuen Habräer. 100 Jahre Kunst in Israel (Nowi Hebrajczycy. 100 lat sztuki w Izraelu), centralną rolę w sztuce żydowskich artystów z Izraela, a więc tych, którzy w odróżnieniu od Żydów wywodzących swoją tożsamość z genealogii, definiują własną tożsamość również poprzez przynależność do ziemi[21]. Motyw palmy, dominujący w graffiti Niepożadana interwencja (widoczny także w Strażni$k u$ ), w wielu pracach pojawia się jako znak, często uproszczony do emblematu, zarówno Izraela[22], jak i ziemi palestyńskiej[23], czy inaczej, Ziemi Świętej lub Ziemi Obiecanej. Palma jest jednocześnie elementem niemal nieodłącznym od zachodnich przedstawień raju: raju rozumianego zarówno jako idealne miejsce na ziemi, jak i rodzaj utopii, którą niegdyś ucieleśniał rajski ogród - Eden[24], a który we współczesnej ikonosferze utożsa-

organizacje palestyńskie w 2000 roku. W 2010 roku mur ten został rozebrany. Zob. http://www. bbc.co.uk/news/world-middle-east-10982961 (data odczytu: 26.10.2010).

[20] Na ten temat zob.: http://www.wodapitna.pl/ programy/palestyna (data odczytu: 27.01.2010).

[21] Zob. katalog wystawy Die neuen Habräer. 100 Jahre Kunst in Israel, Martin-Gropius-Bau, Berlin, 20. Mai - 5. September 2005, herausgegeben von Doreet LeVitte Harten und Yigal Zalmona, Berlin 2005, s. 346.

[22] Ibidem, s. 309, 312 i 350.

[23] Ibidem, s. 349.

[24] Ibidem s. 197.

[25] O tropikalnej wyspie z palmami jako uosobieniu wyobrażenia o raju we współczesnej kulturze (zachodniej) pisze Dan Ringgaard w książce Stedssans [Poczucie miejsca], Århus 2010, s. 15-16.
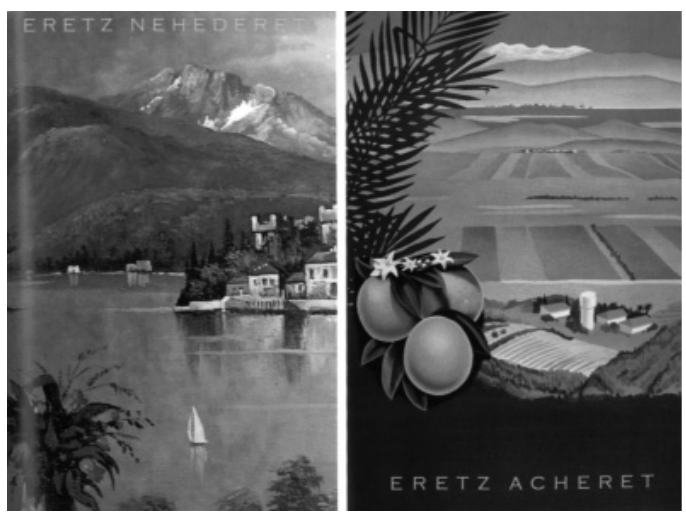

Il. 7.1. David Tartakower, Cudowny kraj, 2004

Il. 7.2. David Tartakower, Dziwny kraj, 2004

miany jest najczęściej z bezludną, tropikalną wyspą z palmami[25].

Nie chciałabym zajmować się polityczną wymową omawianych tu prac. Bardziej interesuje mnie symbolika motywu krajobrazu w sztuce współczesnych artystów izraelskich. W przypadku omawianych graffiti Banksy'ego, szczególnie ciekawe wydaje się spojrzenie na nie poprzez pracę Davida Tartakovera (ur. 1944) z 2004 roku. Jest to dyptyk złożony z takiej samej wielkości przedstawień (il. 7.1, 7.2), z których pierwsze ukazuje krajobraz wysokogórski, o kompozycji zaskakująco przypominającej tę z pracy Banksy'ego, drugie natomiast krajobraz izraelski, w którym motyw palmy pojawia się na pierwszym planie w postaci liścia oraz jako dwa drzewa w oddali, przy domach widocznych w dolinie. Malowidła te opatrzone są „widokówkowymi” napisami: „Eretz nehederet”, a więc po hebrajsku „cudowny kraj” na obrazie z pejzażem górskim oraz „Eretz acheret”, czyli „dziwny (inny) kraj" na krajobrazie izraelskim.

Zestawienie graffiti Banksy'ego z praca Tartakovera zmienia nieco spojrzenie europejskiego odbiorcy: izraelski artysta nazywa krajobraz „alpejski” (obcy) rajem (cudownym krajem), i wobec niego określa swoją ziemię ojczystą jako „inną” (lub „dziwną”). Praca Tartakovera umieszczona była na berlińskiej wystawie w dziale „Alternatywy”. Komentarz w katalogu uściśla tytuł dzieła jako poszuki- 
wanie alternatywnych form wizualnych, przedstawianie świata, który różni się od status quo kraju ojczystego artystów. Szukanie alternatywnych motywów, form czy środków wyrazu w sztuce miałoby odpowiadać wyobrażeniom artystów o miejscu nienaznaczonym konfliktem, dramatem historii. Jak pisze autor komentarza, „(w dziejach Izraela A.M.) obok historii konfliktu istnieje historia ciągłych prób, by sytuację polityczną i społeczną odmienić na lepsze”. Dążenia te widoczne są także w sztuce, ujawniając „marzenie o pokoju, (które) jest istotną częścią izraelskiego społeczeństwa"[26].

Takim wymarzonym miejscem na ziemi będzie dla izraelskiego artysty z pewnością miejsce Inne niż jego własne. Ową „inność” określać będzie położenie geograficzne: zamiast południowego - północne, wschodniego - zachodnie. Taka wzajemna „inność” określa relację krajobrazów przedstawionych w pracy Tartakovera. W przedstawieniu górskiego, zachodniego krajobrazu dominuje atmosfera przytulności i otwartości (wynikająca z pozycji widza); w krajobrazie „tutejszym" wyczuwalny jest niepokój i niedostępność (widz spogląda na dolinę jak gdyby z ukrycia); w krajobrazie „alpejskim” widzimy wieże zabytkowe, którym w przedstawieniu ziemi izraelskiej odpowiada wieża obserwacyjna.

Podobna „inność” określa relację między krajobrazami przedstawionymi w graffiti Okno na Zachodni Brzeg i Niepożądana interwencja, z tą zasadniczą różnicą, że tutaj zarówno „tropikalny”, jak i „północny” krajobraz odpowiadają stereotypowym, wyidealizowanym wyobrażeniom, inaczej niż u Tartakovera, gdzie jedynie krajobraz „północny” przypomina widok z kartki wakacyjnej. Co ciekawe, motyw północnego krajobrazu odnajdziemy też u innych izraelskich artystów. Konotacje „północy” jako miejsca „chłodniejszego”, przynoszącego „ulgę”, a więc tym samym miejsca innego niż gorące (dosłownie i metaforycznie) miejsce ojczyste, świetnie oddaje praca Yehudit Sasportas (ur. 1969).

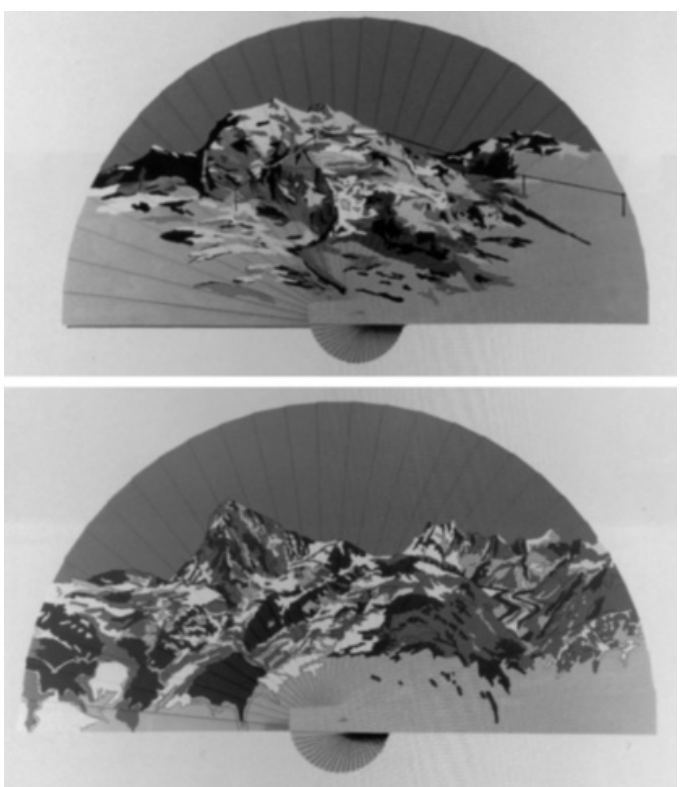

Il. 8. Yehudit Sasportas, Wachlarze, seria 2001-2003

Artystka wykonała cykl malowideł wysokogórskich krajobrazów, które umieściła nie na płótnie czy innym typowym podłożu, lecz na drewnianych wachlarzach (2001-2003, Fans, il. 8). W ten sposób uzyskała efekt „ochłody”, kojarzonej z ośnieżonymi szczytami wysokich gór. Co więcej, uwydatniła też skojarzenia z Północą - rozłożone w półokręgi wachlarze z naniesionymi plamami barwnymi, które dość schematycznie oddają pasma górskie, przypominają rozłożone mapy północnej półkuli ziemskiej.

Bansky pokazuje zatem dwa wyobrażenia „cudownego kraju”. Jedno z nich jest zupełnie odmienne od krajobrazu typowego dla szerokości geograficznej, w której zostało wykonane, odpowiadając wyobrażeniom raju (czy też alternatywnego miejsca przynoszącego „ulgę”), jakie odnajdujemy u współczesnych izraelskich artystów; tytuł pracy - Okno na Zachodni Brzeg - uruchamia konotacje nie tylko w kierunku Zachodniego Brzegu, ale też w stronę Zachodu, świata zachodniego, ukazanego na przeciwnym „brzegu” jeziora. Dru-

[26] Die neuen Habräer..., s. 488. 
gie z przedstawień, Niepożądana interwencja (Plażowi chłopcy), odpowiada wyobrażeniom raju przede wszystkim w kulturze zachodniej, w mentalności turystów odwiedzających Izrael, ale jednocześnie wpisuje się w symbolikę wizualną zarówno Izraela, jak i Palestyny. Fakt umieszczenia przez Banksy’ego zbiorników wodnych - jeziora i morza - w tych utopijnych, a więc nieistniejących krainach, pobrzmiewa dość ironicznie w zestawieniu $\mathrm{z}$ dyptykiem Tartakovera, gdzie morze jest częścią krajobrazu izraelskiego - „dziwnego” co prawda, ale jednak realnie istniejącego. Każde $\mathrm{z}$ „cudownych miejsc” Banksy’ego - północne i południowe - przedstawione zostało jako miejsce nieosiągalne. Jednak - co istotne - każde z nich nieosiągalne jest w inny sposób.

Zastosowanie techniki fotorealizmu w obu przypadkach pozwala widzowi „zatopić się” w widoku, kontemplować oglądany krajobraz. Okno na Zachodni Brzeg szczególnie sprzyja takiemu odbiorowi - okno to nie dziura wybita siłą w murze, lecz „naturalny” dla większości pomieszczeń mieszkalnych element. A widz znajduje się w ,przestrzeni mieszkalnej": wygodne fotele, umieszczony pomiędzy nimi stolik, na którym stoi wazon z kwiatkiem, fantazyjnie upięte zasłony wszystko to wytwarza wrażenie przytulności i domowej atmosfery, a jednocześnie doskonale współgra $\mathrm{z}$ wyobrażeniem miejsca idealnego, niedotkniętego konfliktem, a zatem „innego” niż ziemia podzielona murem, tak jak „inny” jest „północny” krajobraz. Fotele zachęcają, by w nich usiąść, cieszyć się miłą atmosferą i widokiem, który roztacza się za oknem. Jednak, co oczywiste, nie są to fotele przeznaczone dla ludzi - ich skala kilkukrotnie przerasta wymiary mebli dostosowanych do przeciętnego wzrostu dorosłego człowieka. Niedostępność foteli dla widza podkreśla jeszcze technika, w jakiej zostały przedstawione zastosowanie grubego, czarnego konturu, wypełnionego równomiernie białą płaską

[27] Takiego zwrotu używa dziennikarz BBC w cytowanym wywiadzie. plamą barwną odrealnia meble, przypomina, że oglądamy graffiti namalowane na murze, nadaje im - w zestawieniu $\mathrm{z}$ fotorealistycznym krajobrazem - cech groteskowości i satyry. Nie jest to, wbrew pozorom, miejsce, w którym można mieszkać; to raczej „dziwny” dom[27].

Praca Niepożadana interwencja (Plażowi chłopcy) przedstawia wybitą w murze dziurę, przez którą widać plażę i palmy. Poniżej dziury ukazane są sylwetki dwóch kilkuletnich chłopców z wiaderkami, którzy bawią się niczym na plaży - ale jednak nie na niej, lecz pod dziurą. Plaża pozostaje pusta, niedostępna dla dzieci (które jej nawet nie widzą), co jest podkreślone przez zastosowanie dwóch odmiennych konwencji: fotorealistycznej w przypadku plaży z palmami i szablonowej w przypadku sylwetek chłopców, przez co te dwa elementy przedstawienia wydają się należeć do wzajemnie nieprzystających systemów reprezentacji, dwóch różnych światów. $W$ odczytaniu tej pracy również posłużę się innym obrazem. W 1985 roku amerykański artysta żydowskiego pochodzenia, Ronald B. Kitaj (1932-2007) namalował obraz zatytułowany Arabs and Jews [Jerusalem] (Arabowie i Żydzi [Jerozolima], il. 9). Obraz ten przedstawia dwoje dzieci, które siedzą naprzeciwko siebie na kanapie w przytulnym pokoju (co znaczące - w jednym, wspólnym pokoju), lecz każde $\mathrm{z}$ nich zatopione jest we własnych myślach, jak gdyby porzuciły przed chwilą zabawę pluszowymi misiami, leżącymi na podłodze. Najistotniejszy wydaje się fakt, że nie sposób rozróżnić, które $\mathrm{z}$ przedstawionych dzieci jest Arabem, a które Żydem (to rozróżnienie sugeruje jedynie tytuł). Podobnie jest w pracy Banksy'ego - tu również beztrosko bawiący się chłopcy są niemalże identyczni. W kontekście obrazu Kitaja, ale także w kontekście muru, na którym znajduje się graffiti, można pokusić się o odczytanie przedstawionych na nim postaci dzieci, wyglądających jak bliźnięta, jako Araba i Żyda, którzy są „tacy sami”, posiadają wspólne korzenie (pochodzą od Abrahama) i wspólną matkę (ziemię - sugeruje to krajobraz ukazany nad nimi). Przedstawienie raju 


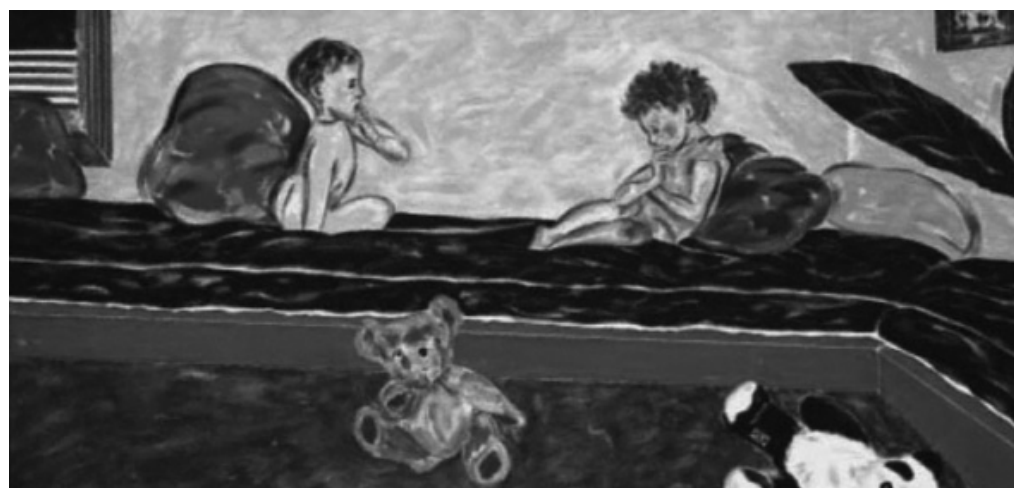

Il. 9. Ronald B. Kitaj, Arabowie i Żydzi (Jerozolima), 1985 w sąsiedztwie dwojga identycznie wyglądających, niewinnie bawiących się dzieci można też czytać jako odwołanie do biblijnego raju i historii Adama i Ewy - gdyby nie zjedzenie owocu „poznania”, a więc nabycie umiejętności „rozróżniania”, dzieci Boga nie zostałyby $\mathrm{z}$ raju wypędzone. Nawiązanie do raju może być tu też rozumiane jako przypomnienie o wspólnym początku. Nie należy jednak zapominać, że chłopcy są częścią przedstawienia - utopii - i tylko dlatego mogą bawić się, nieświadomi podziałów, nieznający różnic, nierozróżnialni. Utopijność krajobrazów ukazanych w graffiti Banksy'ego - Ataku sztuki, Niepożądanej interwencji (Plażowych chłopcach), Oknie na Zachodni Brzeg, Strażniku i Uchyl rąbka - polega także na nadaniu przedstawieniom wymiaru bezczasowości: nie widać tu żadnych budynków ani innych śladów przeszłości i ludzkiej działalności. To dość istotna różnica w stosunku do przedstawień Tartakovera, gdzie pojawiają się ślady człowieka, które w obrazie Cudowny kraj można określić jako ślady historycznej przeszłości. Nasuwa się tu inna, nawiązująca do motywu krajobrazu praca autorstwa izraelskiego fotografa Roi Kupera (ur. 1956), którą można czytać jako swego rodzaju ironiczny komentarz do prób uciekania od historii do pozornie bezczasowej natury. Jest to cykl pięciu niemalże identycznych fotografii, zatytułowanych Nie ma ucieczki od przeszłości (2001), przedstawiających ten sam wycinek plaży, na brzegu której usytuowany jest widz (il. 10). Mimo wrażenia identyczności, na każdym ze zdjęć widać jednak, co oczywiste, drobne zmiany, przede wszystkim w układzie fal morskich i chmur, wskazujące na upływ czasu. Co więcej, sam fakt zastosowania medium fotografii, uważanego często za dokumentujące przeszłość, przeczy pozornej bezczasowości przedstawienia. W fotografiach tych, umieszczonych w dziale „Alternatywy” na berlińskiej wystawie, pobrzmiewa też nostalgiczny nastrój, pozbawiona złudzeń tęsknota za miejscem bezimiennym i nienaznaczonym przeszłością. Jak pokazują prace Banksy'ego, ale także Tartakovera, to, co wydaje się rajem widziane $\mathrm{z}$ jednego miejsca, niekoniecznie nim jest, gdy patrzymy z „drugiej” strony. Omówione tu przedstawienia dotykają problemu dualistycznych podziałów, charakteryzujących wyobrażenia o miejscach i ludziach w nich żyjących, i względem siebie identyfikowanych. Kitaj przedstawia $d$ woje takich samych dzieci znajdujących się we wspólnej przestrzeni, Tartakover ukazuje nam $d$ wa różne kraje: utopię i do czego powrócę - heterotopię, Banksy maluje $d$ wa różne wyobrażenia raju w miejscu, które jest raju całkowitym przeciwieństwem oraz dwoje identycznie wygladajacych dzieci na murze, który ma oddzielić dwie ludzkie populacje.

Michel Foucault w eseju Inne przestrzenie[28] podkreśla, że w dwudziestym wieku zaczyna się epoka, w której miejsce staje się

[28] M. Foucault, Inne przestrzenie, przeł. A. Rejniak-Majewska, „Teksty Drugie” 2005, nr 6 (96). Oryginalny tekst z $1984 \mathrm{r}$. napisany został na podstawie wykładu, który Foucault wygłosił w 1967 r. 

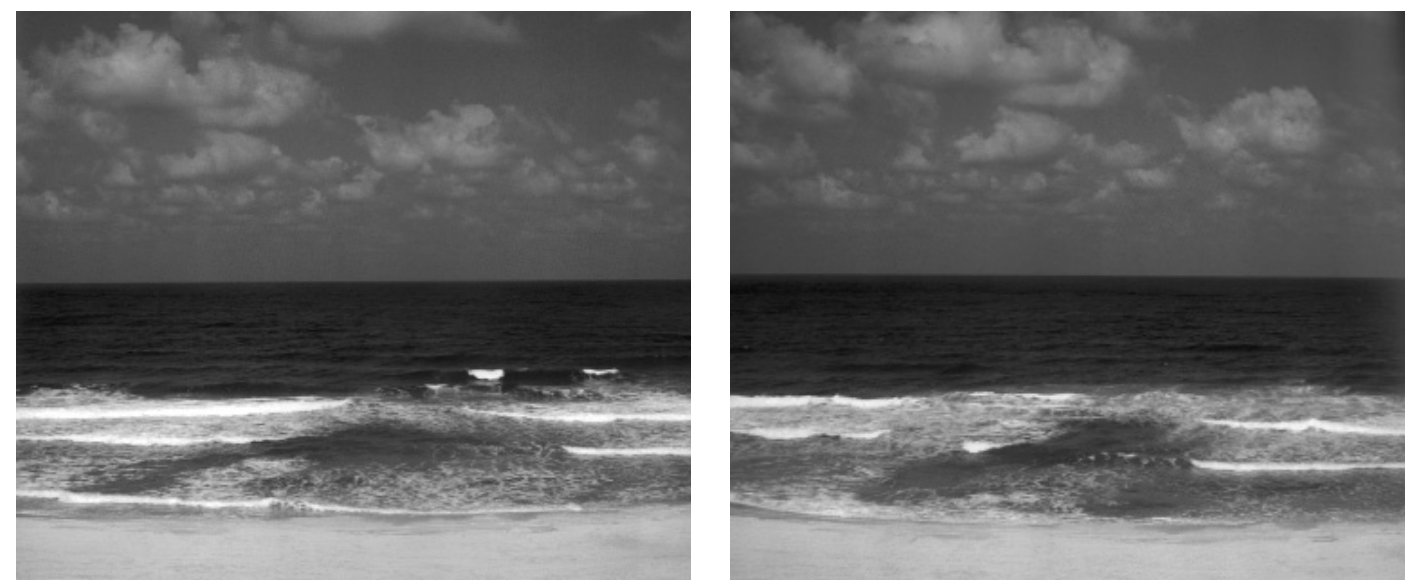

Il. 10. Roi Kuper, Nie ma ucieczki od przeszłości, seria, 2001

siecią krzyżujących się relacji, podobnie jak tożsamość miejsca w o wiele większym stopniu niż wcześniej definiowana jest $\mathrm{w}$ relacji do innych miejsc, „innych” przestrzeni. Taki sposób definiowania miejsca wybierają Tartakover i Banksy. Co więcej, te „inne” przestrzenie nie oznaczają u Foucaulta po prostu innych miejsc, lecz miejsca, które odbiegają od tego, co stanowi „normę" [29]. „Inne”, a więc nie „normalne”. Foucault wyróżnia dwa rodzaje takich miejsc: utopie i heterotopie. W przeciwieństwie do utopii, a więc miejsc bez miejsca, heterotopie to miejsca, które istnieją. Foucault mówi o nich jako realnie istniejących, odgraniczonych miejscach znajdujących się na marginesach normalnego świata (jako przykłady wymienia cmentarze, szpitale dla umysłowo chorych, więzienia, teatry, enklawy turystyczne, statki).

Tartakover przedstawia dwa miejsca: „cudowny” kraj, utopię oraz kraj „dziwny”, heterotopię. Co istotne, jest to dyptyk. Gdy odniesiemy go do triady Foucaulta: utopia - miejsce normalne - heterotopia, zrozumiemy, że brakuje tu środkowego elementu. W świecie przedstawionym przez izraelskiego artystę miejsce normalne, podobnie jak (z istoty rze-

[29] Stedssans..., s. 84-86.

[30] Stedssans, op.cit., s. 94.

[31] Jak określił barierę dziennikarz BBC w przytoczonym programie. czy) utopia, nie istnieje. Artysta wydaje się mówić, że jego kraj to jedna wielka heterotopia.

Prace Banksy'ego wykonane są w miejscu, które zdefiniowane zostało jako margines, leżący na zewnątrz tego, co po stronie wewnętrznej muru i co samo siebie określa jako centrum, a więc to, co „normalne”. Temu, co po palestyńskiej stronie muru, nadany został status heterotopii. Jest to jednak narracja należąca do tego, kto te podziały ustala. W przeciwieństwie do heterotopii, o których pisze Foucault, na Zachodnim Brzegu heterotopia wyraźnie wyznaczona została przez konkretny podmiot stawiający mur, przez ową „drugą” stronę.

Banksy podważa ten dychotomiczny (a więc i hierarchiczny) podział na centrum i margines, miejsce "normalne” i heterotopię. W terminologii Foucaulta heterotopie charakteryzują się tym, że krytycznie odzwierciedlają, podważają i odwracają ustalony porządek centrum. To „drzazga w oku” tych, którzy należą do centrum[30]. Dzięki graffiti Banksy'ego, namalowanym po palestyńskiej stronie muru, mamy wrażenie, że jako widzowie oglądający obrazy namalowane na tym „dziwnym płótnie”[31], znajdujemy się wewnatrz (a w przypadku Okna na Zachodni Brzeg wręcz we wnętrzu mieszkalnym), nie zaś, jak chciałby mur, na zewnątrz. Co więcej, Banksy, podobnie jak Tartakover, również mówi, że normalne miejsce nie istnieje - jed- 
nak w tym przypadku nie chodzi, jak u Tartakovera, o zwyczajną normalność (pokój), ale o owo miejsce po drugiej stronie muru, którego dyskurs polega na definiowaniu samego siebie jako „normalnego”. „Przebijając” mur, Banksy pokazuje, że po drugiej stronie nie ma „normalnego" miejsca. Jest natomiast jego przeciwieństwo, któremu ironicznie i przewrotnie nadana została postać utopii, a więc miejsca doskonałego - ale nierealnego. Jednak pokazując wyidealizowane krajobrazy, Banksy wydaje się tym samym mówić, że po drugiej stronie nie ma wroga. Kwestionując więc „normalność" drugiej strony (w jej własnym dyskursie), Banksy jednocześnie przenosi palestyńskiego widza w krainę marzeń. Naruszając relację między wnętrzem a zewnętrzem, podważa dyskurs tych, którzy tworzą podziały i wyznaczają linie demarkacyjne, a jednocześnie „kolaboruje” z widownią, daje jej „wodę”.

Na podobnej zasadzie „przebijanie” bariery środkami malarskimi, malowanie pęknięć wokół wyłamanych w niej otworów, podważa retorykę muru, opartą na denotowaniu siły, trwałości i niezniszczalności. Wyłamywane w murze otwory zmieniają postrzeganie struktury betonowej ściany, która w Ataku sztuki i Niepożadanej interwencji (Plażowych chłopcach) staje się krucha, łatwo zniszczalna (może ją przebić dziecko) i przemijalna. Trwałość i niezniszczalność zostają przekształcone w kruchość i przemijalność, a zwarta materia betonu w nieuchwytną materię wody, nieba i powietrza, co w najczystszej postaci objawia się w Ataku sztuki, gdzie betonowy mur zamieniony zostaje w niebo i obłoki, co odrywa to miejsce od ziemi i przenosi je gdzieś na (również symbolicznie rozumiane) wyżyny.

W Strażniku twarda ściana okazuje się wykonana $\mathrm{z}$ miękkiej materii, a w Uchyl rąbka z papieru. Graffiti Okno na Zachodni Brzeg w największym stopniu oswaja mur, czyniąc z niego zwykłą ścianę wewnątrz przestrzeni mieszkalnej. Okno, szerokie na trzy betonowe panele, wykonane jest w ten sposób, że złącza pomiędzy panelami zamalowane są białą farbą, naśladującą pionowe podziały okienne.
Banksy podważa zatem fizyczną stabilność muru, ale też nieodłączne od niego znaczenia, jego retorykę władzy, niezniszczalności i nieprzekraczalności. Graffiti brytyjskiego artysty czynią z przestrzeni zewnętrznej wnętrze, i to w podwójnym sensie: wobec „centrum”, jak i - w przypadku Okna na Zachodni Brzeg przemieniając plener w dom, oswajając tym samym obcy, nieprzyjazny mur, który dzięki temu staje się „murem wypędzonych”. Co więcej, Banksy transcenduje mur jako granicę (również tę „w umysłach ludzi”), co jednak nie oznacza odpolityczniania muru. Przeciwnie, poprzez wytworzenie groteskowej sprzeczności między bezczasowymi przedstawieniami wyidealizowanej natury a miejscem naznaczonym historią i konfliktem politycznym, a także sprzeczności między graffiti a okolicą muru (woda vs. brak wody, przestrzeń vs. brak przestrzeni, zieleń vs. wysuszona ziemia) oraz umieszczenie w przedstawieniach groteskowych elementów, jak ponadludzka skala mebli czy dziecko samodzielnie przebijające beton, artysta czyni widza bardziej świadomym siły i opresywności muru. W Niepożądanej interwencji (Plażowych chłopcach) wymowne jest umieszczenie postaci dzieci na wysokości odgradzającej mur siatki z drutem kolczastym, przez którą bawiących się chłopców oglądają przechodnie.

Wspomniany Lefebvre w książce The Production of Space mówi o tym, że każde miejsce posiada w sobie rezonans innych miejsc, który jest wynikiem współgrania fizycznej przestrzeni, ludzkich działań, a także wyobrażeń i znaczeń symbolicznych, związanych ze sferą kultury i historii, ale też pamięci i fantazji[32]. Na specyfikę danego miejsca składa się też to, co z niego wykluczone[33]. Prace Banksy'ego, ściśle powiązane $\mathrm{z}$ miejscem, w które zostały

[32] Stedssans..., s. 31. Zob. też. A. Zieleniec, Space and Social Theory, Los Angeles, London, New Delhi, Singapore 2007, s. 72-80.

[33] Stedssans..., s. 93. Autor omawia tu teorię miejsca Doreen Massey wyłożoną w jej książce For space (2005). 
wpisane tzw. site-specific art, uruchamiają tkwiący w nim rezonans innych miejsc, są projekcją pragnień, a jednocześnie gorzkim zaprzeczeniem tego, czym owo miejsce rzeczywiście jest. Do tego rezonansu należą wyobrażenia miejsc Innych jako „cudownych”, rajskich. One same są jednak rezonansem tego, czego w graffiti Banksy'ego nie odnajdziemy i czego dotkliwy brak jego prace uwydatniają: miejsca normalnego. Utopii.

\section{Kamera i poeta doctus? O filmach Edwarda Żebrowskiego z perspektywy lotu ptaka}

\section{ANDRZEJ SZPULAK}

Jeśli rozważa się kwestię białych plam w dorobku polskiego piśmiennictwa filmowego poświęconego historii rodzimej kinematografii, to twórczość Edwarda Żebrowskiego staje się obiektem szczególnie ważnym i ciekawym. Nie napisano o niej prawie nic, a przecież, gdyby zapytać jakąkolwiek kompetentną osobę, musiałaby odpowiedzieć, że było warto i było o czym. Fakt, że reżyser zrealizował samodzielnie zaledwie pięć filmów (dwa filmy krótkie oraz trzy pełnometrażowe filmy fabularne) [1], po czym z powodu choroby zamilkł, nie powinien być powodem do ustawiania go w drugim czy może trzecim szeregu polskich reżyserów, a tym bardziej nie powinien być powodem odsyłania go w niebyt. Ta ostatnia praktyka, trzeba przyznać dominująca w recepcji dzieł Żebrowskiego, jest tym boleśniejsza, że owo odesłanie w niebyt odbywa się właśnie bez komentarza. Garstka krótkich i rozproszonych tekstów krytycznych, czy wywiadów towarzyszących premierom kolej-

[1] Wraz z K. Zanussim E. Żebrowski współreżyserował jeszcze dwa filmy w Zachodnich Niemczech. Były to Die Nachtdienst (1975) oraz Die Unerreichbare (1982).

[2] B. Zmudziński, Edward Żebrowski - kino dyskursu moralnego, w: Autorzy kina polskiego, red. G. Stachówna i J. Wojnicka, Kraków 2004, ss. 79-90.

[3] K. Mąka-Malatyńska, A Attempt To Read Lem's And Żebrowski's "The Hospital of The Transfiguration” In A New Way, „Images” vol. VI, nr 11-12, 2008, ss. 57-66. nych utworów z natury rzeczy nie może być traktowana jako dostateczne wyjaśnienie fenomenu tego kina. A poza nimi jest już niewiele. Syntetyczny artykuł Bogusława Zmudzińskiego, opublikowany w tomie poświęconym mniej eksponowanym, a istotnym twórcom polskiego filmu[2], czy też odnoszący się do zagadnienia bardziej szczegółowego i jednego tylko dzieła tekst Katarzyny Mąki-Malatyńskiej [3], choć budzą uznanie, tylko cząstkowo oddają rangę i wagę przedmiotu. Zresztą, co symptomatyczne, pierwsza ze wspomnianych publikacji w tego rodzaju projekcie, jakim sa Autorzy kina polskiego, po prostu musiała się znaleźć, zaś druga zrodziła się z zainteresowania autorki problemem obrazów Zagłady w kinie polskim, dla którego Szpital Przemienienia (1978) stał się ważną egzemplifikacją.

W świadomości profesjonalnych filmoznawców autor Dnia listopadowego (1970) funkcjonuje oczywiście jako twórca dość wybitny, ale nie wzbudzający emocji, a nawet nieco anachroniczny. W świadomości zagorzałych miłośników polskiego kina funkcjonuje przede wszystkim jako artystyczny partner Krzysztofa Zanussiego z początków jego kariery, błyszcząc światłem odbitym. Znana jest też czasem jego działalność scenopisarska, czy pedagogiczna. Natomiast w świadomości tylko nieco mniej zagorzałych miłośników kina nie funkcjonuje on niestety w żadnym stopniu, nawet na poziomie rozpoznawalności nazwiska. Zapewne jedynie w środowisku 